\title{
A New Approach for Utilization of Modified Epicoccum Nigrum Biomass by Ferric Chloride Nanoparticles for Biosorption of Thorium
}

\author{
Shimaa S Hussien*, Osman A Desouky and Mohamed Elkattan
}

Nuclear Materials Authority, El-Maadi, Cairo, Egypt

\begin{abstract}
Biosorption of thorium by Epicoccum nigrum biomass was determined at varying experimental conditions using a batch technique. High biosorption efficiency was observed for dead biomass $500 \mathrm{mg} / 50 \mathrm{~mL}$ of $E$. nigrum within $60 \mathrm{~min}$ of contact, at $\mathrm{pH} 6.8$, temperature of $30^{\circ} \mathrm{C}$ and agitation speed of $150 \mathrm{rpm}$ with $150 \mathrm{mg} / \mathrm{L}$ as initial thorium concentration. Scanning electron microscope (SEM) equipped with electron dispersive X-ray (EDX) was used for characterization of the biosorbent agent after and before biosorption process to identify composition of elements of the dead biomass after and before biosorption of thorium. Infrared spectroscopy (FTIR) study revealed that the amide groups interact with thorium particles, which was accountable for the stability of thorium complex. This analysis confirmed the presence of proteins as stabilizing and capping agents. Furthermore, $\mathrm{X}$-ray diffraction (XRD) analysis reveals the presence of metallic thorium ions.
\end{abstract}

Keywords

Epicoccum nigrum, Ferric chloride nanoparticles, Biosorption and thorium

\section{Introduction}

There are many methods used for recovering metal ions from pregnant solution such as chemical precipitation, ion exchange, solvent extraction and sorption [1]. These traditional techniques suffer from several disadvantages, such as high consumption of reagent and energy, high operational cost, low selectivity and generation of secondary pollutants [2]. Therefore, alternative techniques for the bioremediation of metal using bacteria, fungi and yeast are currently being investigated. Biosorption can be defined as the removal of metal or metalloid species, particulates and compounds from solution by non-living and living biological materials [3]. The fungus-mediated green technology approach towards the biosorption of metal has several advantages, such as easy and simple scaling up, easy processing, economic viability, biomass handling, and recovery of large surface areas with optimum growth of mycelia [4]. Using dead biomass is more advantageous than the using live biomass as there are no requirements of growth media or nutrients, no toxicity concerns. Also, easy techniques were developed to desorb contaminants from the dead biomass and reuse them [5].

Fungi cell walls contain large quantity of polysaccharides and proteins, which offer many functional groups (such as carboxyl, sulphate, hydroxyl, phosphate and amino groups) for binding metal ions [6]. The reaction between microorganisms and metal ions have been well investigated [7] and the ability of microorganisms to extract and/or biosorb metals is already used in biotechnological processes such as bioremediation through the biosorption of toxic metals such as thorium. Studies in the literature have reported the use of dead fungal biomass for biosorption of metal ions as nickel by Hypocrea lixii [8]. The desorption process has the purpose of recovering the biosorbed metals while regenerating the biomass that could be used in subsequent sorption and desorption cycles [9]. Fungi are frequently used in bioremediation processes since they are able to grow and adapt under extreme conditions of $\mathrm{pH}$, nutrient and temperature availability, as well as at high metal concentrations [10].

Thorium is considered one of the strategic that imparting high strength and creep resistance at elevated temperatures [11]. Thorium Th is a naturally occurring radionuclide with nuclear importance due to its application as an alternative fuel by converting it into $233 \mathrm{U}$. It is majorly resulted as a strong gamma-emitting by-product during nuclear reactor

*Corresponding author: Shimaa S Hussien, Nuclear Materials Authority, El-Maadi, Cairo, Egypt

Accepted: November 19, 2018

Published online: November 21, 2018

Citation: Hussien SS, Desouky OA, Elkattan M (2018) A New Approach for Utilization of Modified Epicoccum Nigrum Biomass by Ferric Chloride Nanoparticles for Biosorption of Thorium. Aspects Nanotechnol 1(1):40-51 


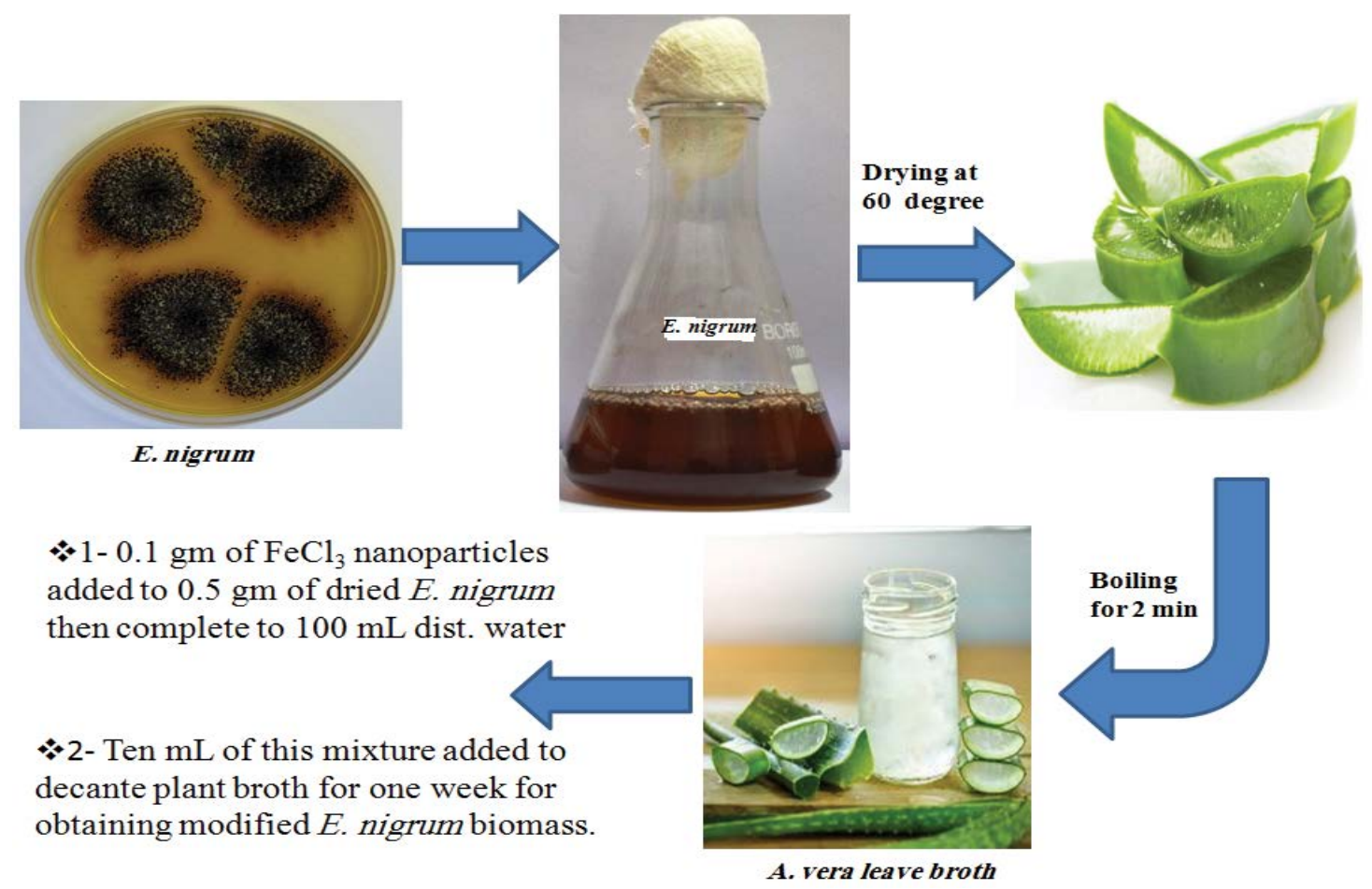

Figure 1: Scheme visualizing preparation of modified $E$. nigrum by $\mathrm{FeCl}_{3}$ nanoparticles using $A$. vera leave broth.

operations and is found in various industrial effluents [12] Nanotechnology research deals with manipulation and production of nanoparticles that have new properties, which differ from their corresponding bulk material form. These differences are probably due to effects such as quantum size effect, surface effect, and macro-scopic quantum tunneling [13]. Nanoparticles have been widely studied over the past decade due their application in different areas such as recording media, catalysts, sensors, etc. [14].

This paper reports a novel approach for the modification of the surface area of the fungal by ferric chloride nanoparticles to be used in the uptake of thorium by dead biomass of the filamentous fungus $E$. nigrum. A study of biosorption coupled with process of optimization of the surface area using ferric chloride nanoparticles was conducted. Furthermore, optimization of different physico-chemical parameters, i.e., $\mathrm{pH}$, temperature, initial metal concentration, interaction time and others, were done to ensure efficient uptake of thorium.

\section{Materials and Methods}

\section{Microorganism and biosorbent preparation}

E. nigrum was isolated in Fungal Laboratory of Zagazig University. Modified Czapek's-Dox agar (MCDA) was used for growth of the tested fungi. The medium composition is as follows (g/L): sucrose 30; $\mathrm{NaNO}_{3} 3 ; \mathrm{KH}_{2} \mathrm{PO}_{4} 1 ; \mathrm{MgSO}_{4} 7 \mathrm{H}_{2} \mathrm{O} 0.5$; $\mathrm{KCl} 0.5 ; \mathrm{FeSO}_{4}$ 0.01; yeast extract 10 and agar-agar [15]. The culture was incubated for 15 days at $30^{\circ} \mathrm{C}$, and $150 \mathrm{rpm}$. After 7-8 days of growth, the harvested cells were washed twice with deionized distilled water till the $\mathrm{pH}$ of the wash solution was in the near neutral range. Then, it was dried at $60^{\circ} \mathrm{C}$ for $24 \mathrm{~h}$ before use. The dried mat was ground to obtain uniform sized particles [16].

\section{Preparation of E. nigrum surface area using $\mathrm{FeCl}_{3}$ nanoparticles}

Aloe vera leaf broth is used for the pretreatment of the E. nigrum surface area by $\mathrm{FeCl}_{3}$ nanoparticles. Aloe vera leaf broth prepared by taking $20 \mathrm{~g}$ of thoroughly washed and finely cut $A$. vera leaves in a 500-mL Erlenmeyer flask with $100 \mathrm{~mL}$ of sterile distilled water and then boiling the mixture for 2 min then finally decanting it. For preparation of microorganism $0.1 \mathrm{gm}$ of $\mathrm{FeCl}_{3}$ nanoparticles added to 0.5 gm of dried $E$. nigrum for homogeneity well then completes the volume to $100 \mathrm{~mL}$ with deionized distilled water. Ten $\mathrm{mL}$ of this mixture added to decante plant broth for one week. After that, the mixture was filtrated to obtain modified $E$. nigrum surface area attached by $\mathrm{FeCl}_{3}$ nanoparticles through Aloe vera leaf broth. Then, it was grinded to $125 \mathrm{~mm}$ size for biosorption experiments (Figure 1).

\section{Thorium solution preparation and ferric chloride nanoparticles characterization}

All Thorium stock solution ( $1 \mathrm{~g} / \mathrm{L}$ ) was prepared separately from $\mathrm{Th}\left(\mathrm{NO}_{3}\right)_{4} \cdot 4 \mathrm{H}_{2} \mathrm{O}$ which obtained from Alfa Aesar. The stock solution was prepared by diluting the stock solution to appropriate volume. Particle size of the used iron chloride nanoparticles is measured using dynamic light scattering technique in a $180^{\circ}$ heterodyne-backscatter arrangement using Nanotrac Wave II device. The used nanoparticles show D50 of $100 \pm 10$ nanometer in size with PDI of 0.1528 \pm 0.1. Iron chloride nanoparticles were obtained from Zagazig University, Egypt. The obtained X-ray diffraction spectrum appeared distinct peaks indicating the deposition of crystallized hematite. Diffractogram of the hematite displayed maximum number of peaks to iron oxide between 


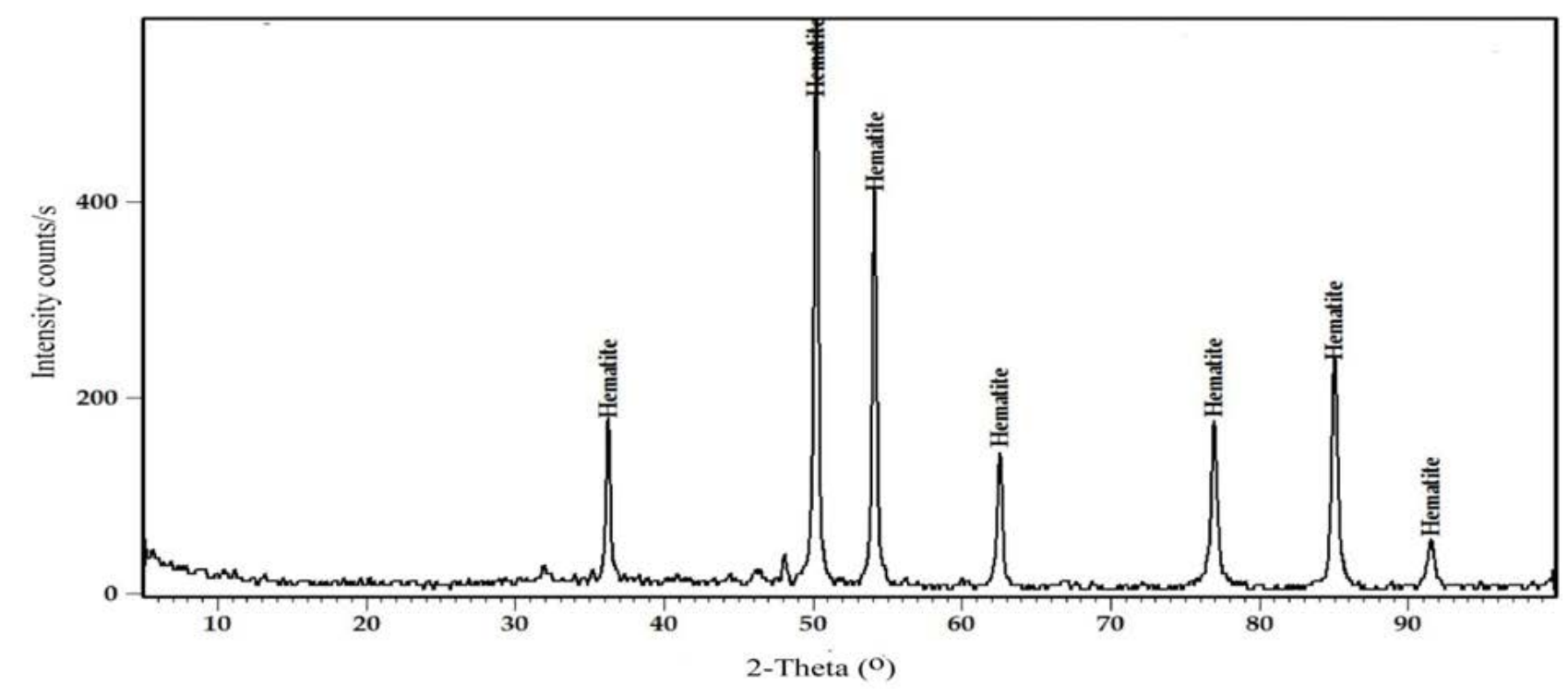

Figure 2: X-ray diffraction spectrum of $\mathrm{FeCl}_{3}$ nanoparticles.

$2 \theta$ of $37.11^{\circ}, 2 \theta$ of $50.37^{\circ}, 2 \theta$ of $54.56^{\circ}, 2 \theta$ of $64.34^{\circ}, 2 \theta$ of $77.35^{\circ}, 2 \theta$ of $86.49^{\circ}$ and $2 \theta$ of $29.56^{\circ}$ as illustrated in Figure 2.

\section{Factors affecting the biosorption process}

Biosorption experiments were conducted with $50 \mathrm{~mL}$ of $50 \mathrm{mg} / \mathrm{L}$ initial concentration of Th(IV) ions solution in $250 \mathrm{~mL}$ Erlenmeyer flask for 60 minutes contact time at room temperature $26 \pm 1{ }^{\circ} \mathrm{C}$. The effect of initial thorium concentration (50-500 mg/L), $\mathrm{pH}(2-6)$, biosorbent dose (0.1$1.5 \mathrm{~g})$, contact time $(10-120 \mathrm{~min})$, temperature $\left(20-60^{\circ} \mathrm{C}\right)$ and agitation speed (50-250 rpm) on the biosorption of thorium was analyzed. These experiments were carried out at the desired $\mathrm{pH}$, temperature, initial metal concentration, contact time, agitation speed and biosorbent dose using $50 \mathrm{~mL}$ of a $100 \mathrm{mg} / \mathrm{L}$ Th(IV) ions solution.

The supernatants were filtered through a (Whatman No. 41) filter paper and the concentration of Th(IV)in the solution was measured before and after equilibrium by (MetertechIno model Sp-5001, UV-Visible spectrophotometer) using arsenazollI [17]. The efficiency (R) of metal removal was calculated using the following equation:

$$
\mathrm{R}=\frac{\mathrm{Co}-\mathrm{Ce}}{\mathrm{Co}} \times 100
$$

Where Co and $\mathrm{Ce}$ are initial and equilibrium metal concentrations, respectively.

\section{Characterization of E. nigrum biomass surface area after pretreatment and biosorption of thorium}

The change in the surface morphology of pore structure, treated and loaded biomass of $E$. nigrum were observed under scanning electron microscope (SEM), Philips XL30 vacuum at $30 \mathrm{KV}$.SEM equipped with energy dispersive $\mathrm{X}$-ray (EDX) to identify the composition of elements of the tested biomasses of $E$. nigrum. The apparatus was presented in nuclear materials authority (NMA), Cairo, Egypt.
Infrared spectrophotometer was used to determine the functional groups presented on the surface of $E$. nigrum biomass before and after loading with Th(IV). The samples were prepared as $\mathrm{KBr}$ discs. The apparatus used was (Model JASCO 4100 FTIR spectrophotometer, Japan) which presented in the Micro Analytical Center, Cairo University, Egypt.

X-ray Diffraction (XRD) patterns of tested samples were recorded using (PHILIPS PW 3710/31 diffractometer with automatic sample changer PW 1775, (21 positions), Scintillation counter, Cu-target tube and $\mathrm{Ni}$ filter at $40 \mathrm{Kv}$ and $30 \mathrm{Am}$. This instrument is connecting to a computer system using $\mathrm{X}-40$ diffraction program and ASTM cards for mineral identification. The apparatus was found in (NMA), Cairo, Egypt.

\section{Desorption study}

Desorption experiments were performed by mixing $E$. nigrum loaded biomass (500 $\mathrm{mg}$ dry weight) with desorbing agents $50 \mathrm{~mL}$ of $\left(0.1,0.2,0.3 \mathrm{~N} \mathrm{HCl}, 0.1,0.2,0.3 \mathrm{~N} \mathrm{HNO}_{3}\right.$ and $0.1,0.2,0.3 \mathrm{~N} \mathrm{H}_{2} \mathrm{SO}_{4}$ ) for $1 \mathrm{~h}$ on a rotary shaker (175 rpm) at $30{ }^{\circ} \mathrm{C}$ for three cycles to study the elution efficiency [18].

\section{Results and Discussion}

The fungus $E$. nigrum was selected to investigate the uptake of thorium from aqueous medium. Some fungi are recognized as hyperaccumulators of heavy metals due to their filamentous morphology and high content of cell wall material [19]. The hyphal wall of fungi has been found to be the primary site of metal ion accumulation owing to the presence of the acetamide group of chitin, amino and phosphate groups in nucleic acids, amino, amido, sulfhydryl and carboxy groups in proteins, and hydroxyls in polysaccharides [20].

\section{Influence of physico-chemical parameters on biosorption}

Physico-chemical parameters affect the removal of thorium from aqueous solution, $[14,21]$. The fungal biomass 
$a$

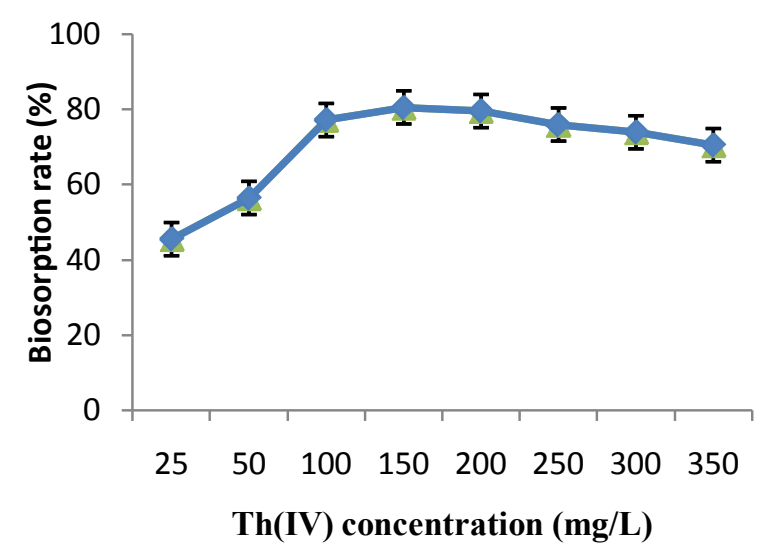

$c$

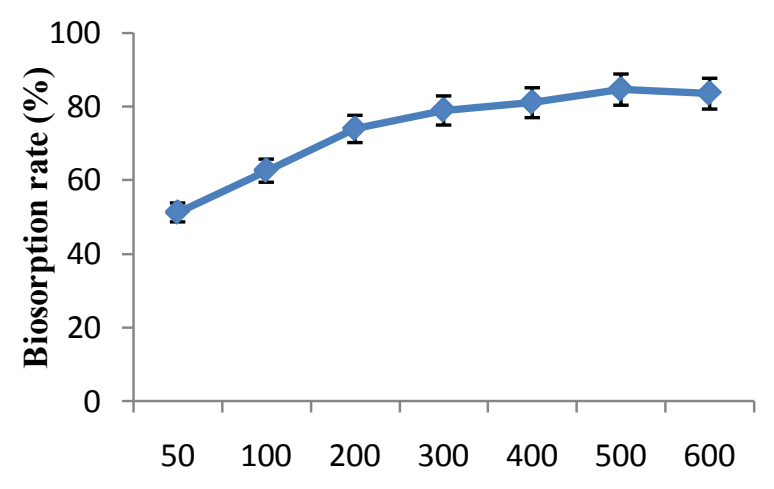

Amount of adsorbent $(\mathrm{mg} / 50 \mathrm{~mL})$

$\boldsymbol{e}$

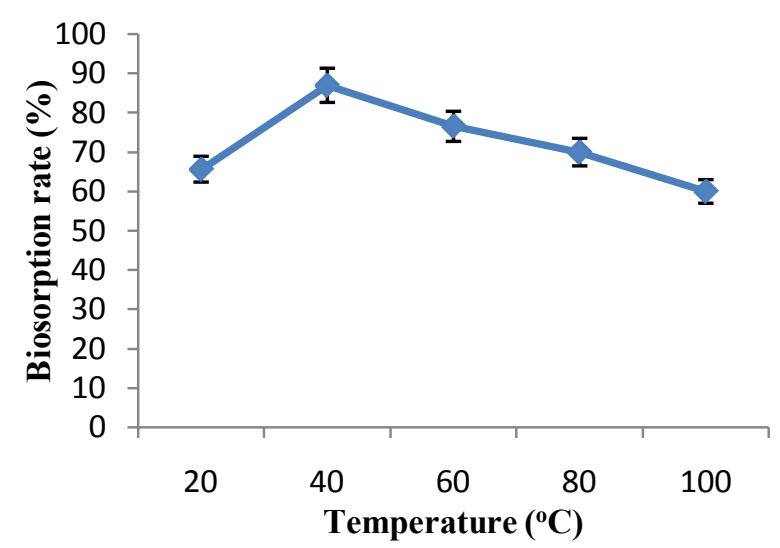

$\boldsymbol{b}$

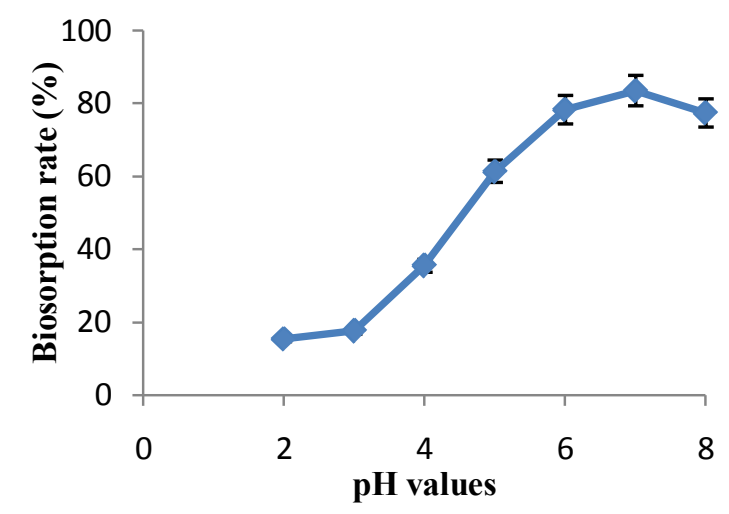

$\boldsymbol{d}$

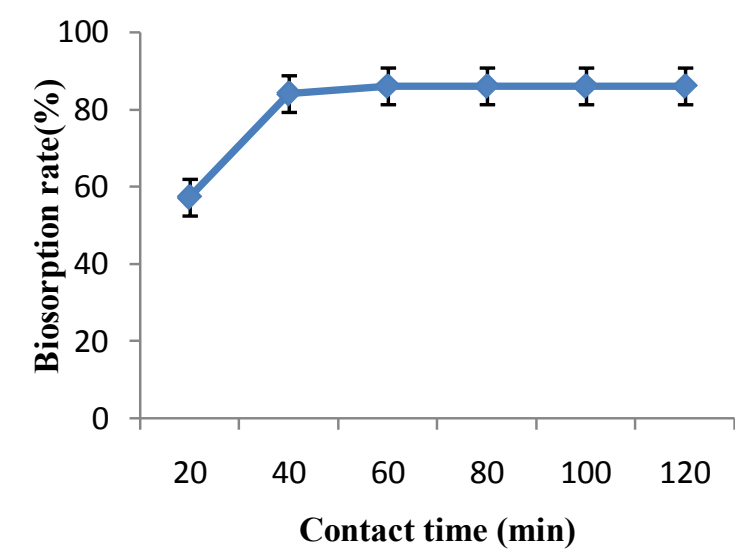

$f$

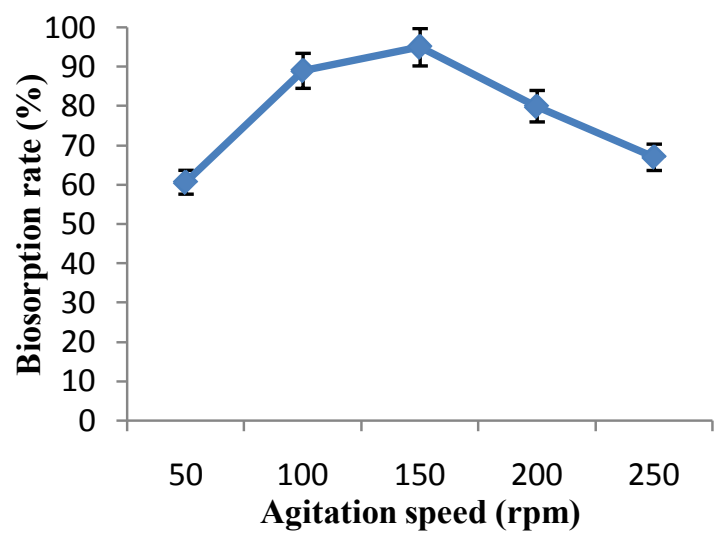

Figure 3: Effect of different parameters on biosorption of thorium by E. nigrum.

(a) Thorium initial concentration; (b) pH values; (c) Amount of adsorbent; (d) Contact time; (e) Temperature; (f) Agitation speed.

cell walls are formed of chitin, chitosan, glucan, lipid, phospholipids, which contain amino groups, carboxyl groups, phosphates, lipids, melanin, sulphates and hydroxides [22]. These functional groups are considered the sites sorption of the metals [23].
Study of the effect of physico-chemical parameters on the biosorption efficiency of thorium by the biosorbent reveals that biosorption percentage of Th(IV) ions follows a decreasing trend as metal ion concentration increased (Figure 3a). The biosorption of Th(IV) ions decreased from $80.48 \%$ to $70.45 \%$ 
Citation: Hussien SS, Desouky OA, Elkattan M (2018) A New Approach for Utilization of Modified Epicoccum Nigrum Biomass by Ferric Chloride Nanoparticles for Biosorption of Thorium. Aspects Nanotechnol 1(1):40-51

with an increase of Th(IV) ions concentration from $150 \mathrm{mg} / \mathrm{L}$ to $350 \mathrm{mg} / \mathrm{L}$, however the biosorption efficiency by free biomass of $E$. nigrum reached to $54 \%$. The maximum biosorption of Th(IV) ions was obtained at concentration of $150 \mathrm{mg} / \mathrm{L}$. This behavior can be due to that, at higher concentrations, the increase of Th(IV) ions concentration probably lead to the increase in the number of ions competing for the available binding sites in the biomass resulted in the limitation of vacant binding sites, which saturate beyond certain concentrations, thus decreasing Th(IV) ions biosorption [24].

Furthermore, thorium biosorption percentage was strongly dependent on $\mathrm{pH}$ (Figure 3b). The capacity of functional groups found on the biomass cell wall surface depends on the $\mathrm{pH}$ of the solution $[25,26]$. Maximum removal of thorium was $83.54 \%$ as observed at $\mathrm{pH} 6.8$ as shown in Figure $3 \mathrm{~b}$. At lower $\mathrm{pH}$ value, the cell wall of $E$. nigrum becomes positively charged and it is responsible for reduction in biosorption capacity. In contrary, at higher $\mathrm{pH}$, i.e. more than $\mathrm{pH} 6.8$, the cell wall surface becomes more negatively charged and therefore the biosorption of Th(IV) onto E. nigrum is more due to attraction between the biomass and the positively charged metal ion. Under alkaline conditions, deprotonation of the heavy metals binding sites and precipitation of Th(IV) ions as insoluble hydroxides or hydrated oxides is believed to be responsible for the decrease in Th(IV) ions biosorption by E. nigrum.

Effect of amount of biosorbent on the biosorption of Th(IV) ions by $E$. nigrum is presented in Figure $3 c$. With an increase in biosorbent amount from 50 to $600 \mathrm{mg}$, the percentage of Th(IV) ions biosorption increased from $51.34 \%$ to $84.66 \%$. Biosorption percentage of Th(IV) ions reached equilibrium at $500 \mathrm{mg}$ biosorbent concentration. Increase in biosorption of Th(IV) ions due to the increase in biosorbent amount could be attributing to increase in surface area that leads to increase in the binding sites and combination of metal ion with the corresponding sites [27].

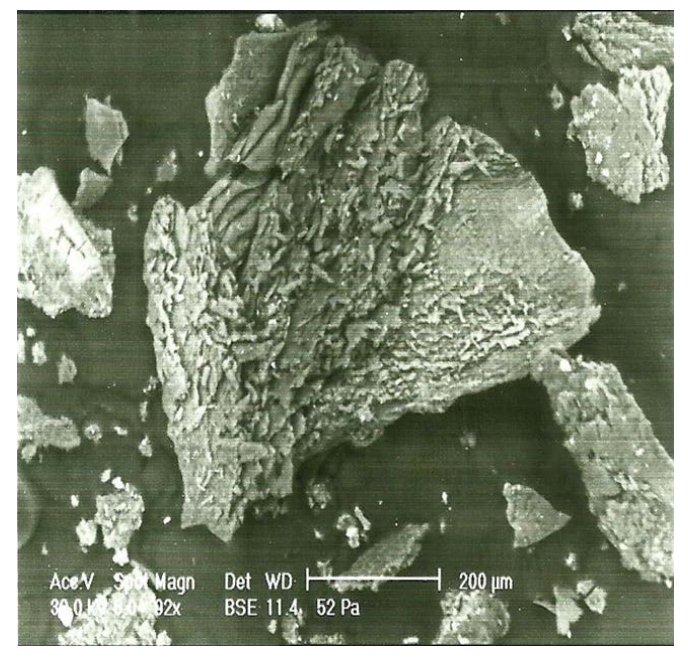

a

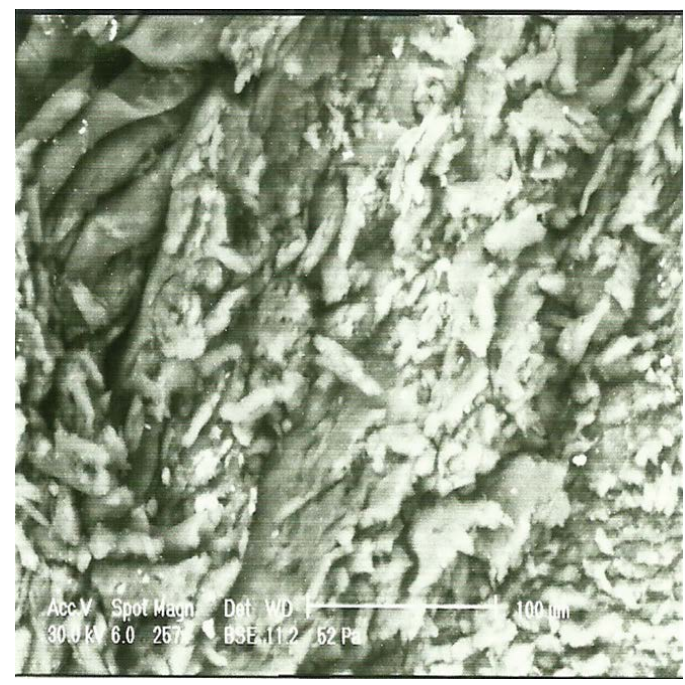

C

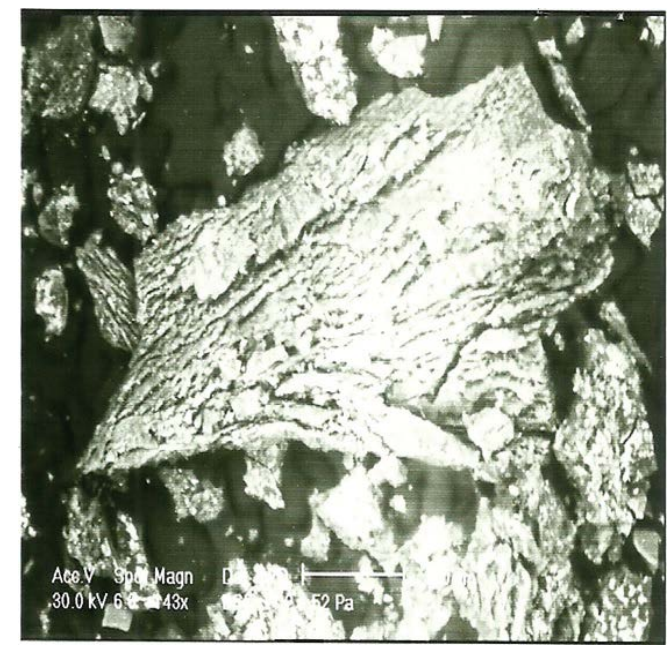

b

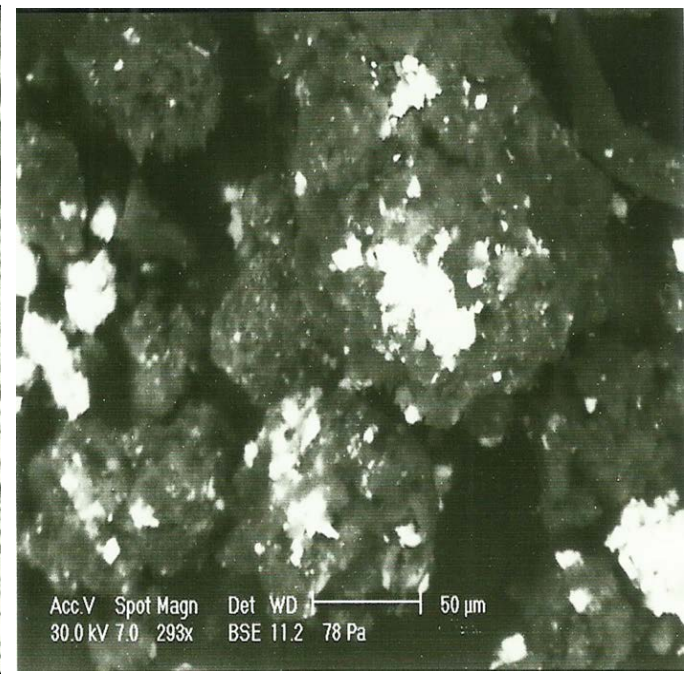

d

Figure 4: SEM micrograph of the surface biomass of dead E. nigrum.

(a) Free dead biomass; (b) Dead biomass modified with ferric chloride nanoparticles; (c) Dead biomass after biosorption of thorium;

(d) Dead biomass after elution by $0.1 \mathrm{~N} \mathrm{HCl}$. 
a

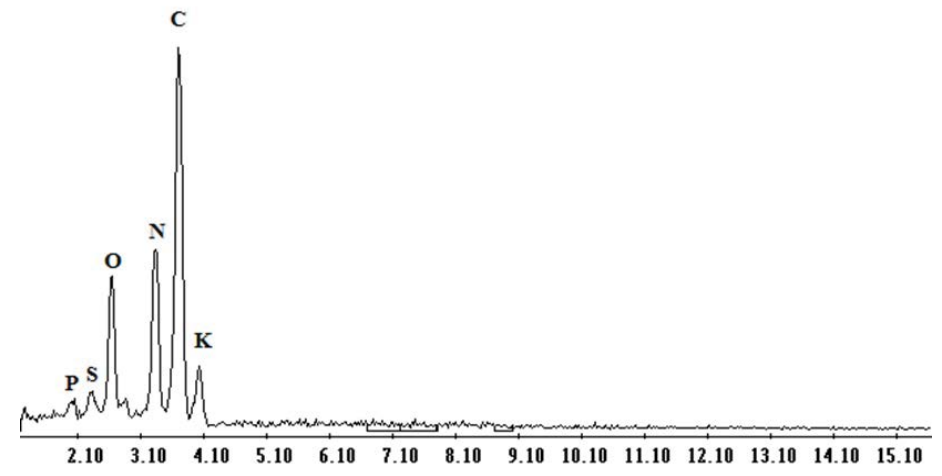

b
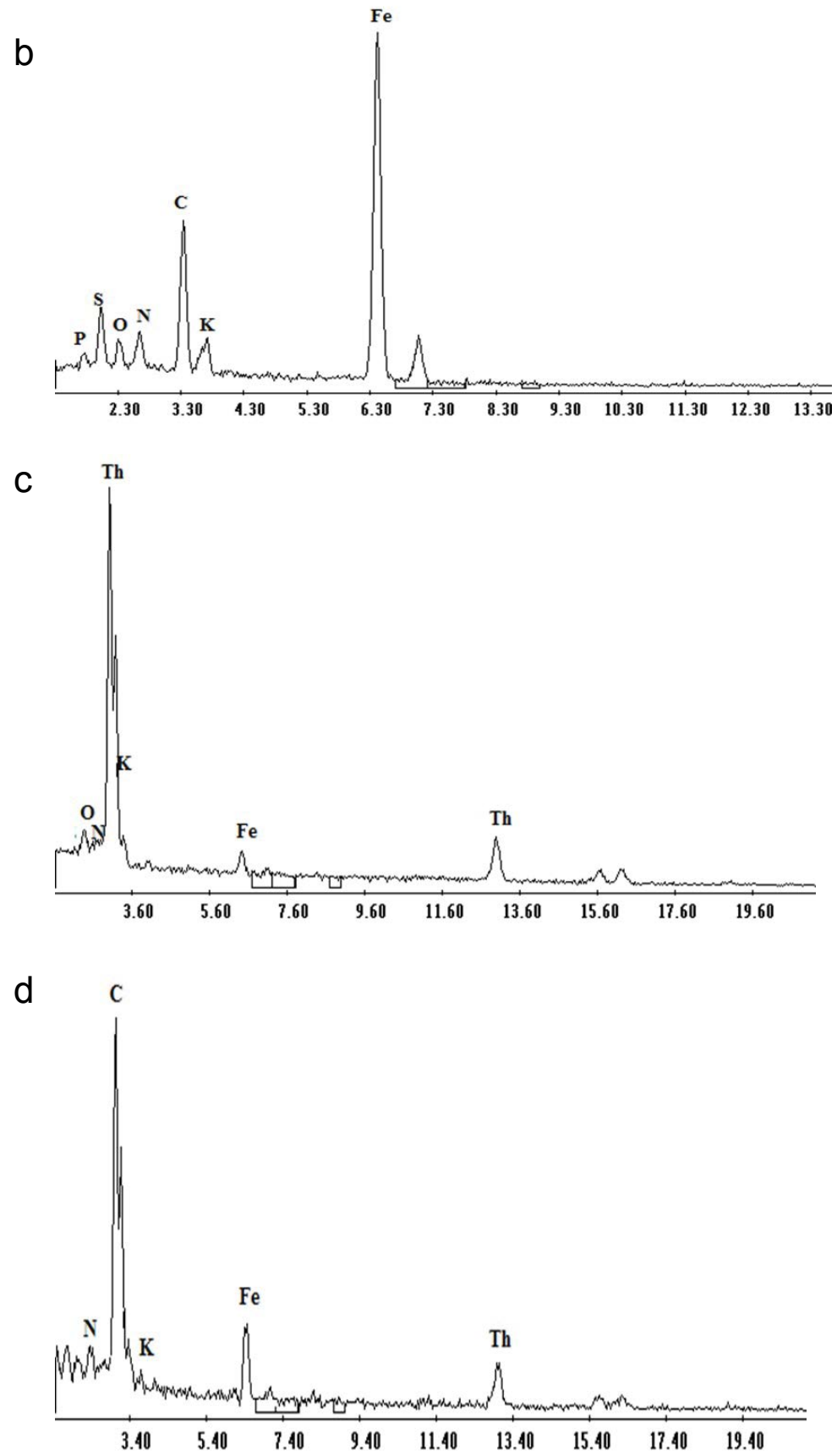

Figure 5: EDX spectra of the surface biomass of dead E. nigrum.

(a) Free dead biomass; (b) Dead biomass modified with ferric chloride nanoparticles; (c) Dead biomass after biosorption of thorium; 9d) Dead biomass after elution by $0.1 \mathrm{~N} \mathrm{HCl}$. 
Figure 3d presents Th(IV) ions biosorption, at different contact time, by $E$. nigrum. It was observed that there are two stages for the biosorption of Th(IV) ions; an initial rapid increase in biosorption percentage during the first 60 minutes, then followed by a plateau at $85.99 \%$ for Th(IV). This indicates that, as the contact time increased, more and more functional groups participated in biosorption of metal ions until it reaches equilibrium. Then when active sites on the biosorbents were filled, rate of biosorption became gradually constant and reached a plateau. In $[14,16]$ reported similar trend of observation whereby the biosorption of nickel by Hypocrea lixii. The influence of temperature on thorium uptake is shown in Figure 3e. Maximum removal about $86.99 \%$ of Th (IV) occurred at $30{ }^{\circ} \mathrm{C}$. Similar observation obtained in [28] as they reported that the increase in biosorption percentages with temperature may be attributed to either an increase in the number of active surface area sites available for biosorption or the decrease in the thickness of the boundary layer surrounding the biosorbent with temperature, so that the mass transfer resistance of adsorbate in the boundary layer decreases. The highest Th(IV) removal about $87.99 \%$ was observed at an agitation speed of $150 \mathrm{rpm}$ as observed in Figure 3f. At high agitation speeds, the suspension is no longer homogenous, a fact impairing metal removal and biosorption process [29].

\section{Characterization of pretreated E. nigrum biomass after biosorption of thorium}

SEM observations: Thorium metals absorbed by the pretreated dead fungal biomass were characterized by morphological and structural analysis. Figure 4a, Figure 4b, and Figure $4 \mathrm{c}$ show SEM photomicrographs of free dead biomass $E$. nigrum modified by ferric chloride nanoparticles before and after biosorption of Th(IV) ions by dead fungal biomass. Modification of the fungal surface area occurred due to formation of smooth characteristic surface as a glue stick coating the surface of the fungal biomass and leads to increasing in irregularity after binding to Th(IV) ions (i.e., Figure 4c). This result may be due to the biosorption affinity between the biomass and the element [30]. Figure 4d shows SEM photomicrograph of dead biomass of $E$. nigrum after elution by $0.1 \mathrm{~N} \mathrm{HCl}$. It was observed that the surface becomes clearer and a lot of biosorbed Th(IV) ions were eluted.

Figure $5 a$, Figure 5b, and Figure $5 c$ illustrates The EDX spectra in the region of mycelium before and after thorium exposure. Figure $5 c$ recorded in the examined region of mycelia indicates existence of signals of Th(IV) ions. However, signals of $\mathrm{C}, \mathrm{N}$ and $\mathrm{O}$ were also observed, indicating the possible presence of proteins as a capping material. This protein matrix maybe responsible for the stabilization (capping material) of Th(IV) metals in the form of a film on the biomass surface. The obtained results agreed with that obtained in [16]. Also, EDX spectra in Figure $5 d$ reveals that, $0.1 \mathrm{~N} \mathrm{HCl}$ eluted Th(IV) ions with high efficiency reached about $80.87 \%$. Table 1 indicates the Elemental analysis of the dead biomass of $E$. nigrum before and after thorium exposure.

IR spectral analysis: FTIR spectral analysis is important to identify some characteristic functional moieties which are responsible of adsorbing metal ions. Figure 6a, Figure $6 b$, and Figure $6 \mathrm{c}$ shows typical FTIR spectra for normal, treated E. nigrum biomasses non-loaded (control), pretreated with ferric chloride nanoparticles and loaded with Th(IV) ions respectively. FTIR spectra of the biosorbents are recorded in the range of $500-4000 \mathrm{~cm}^{-1}$ to ascertain the information of

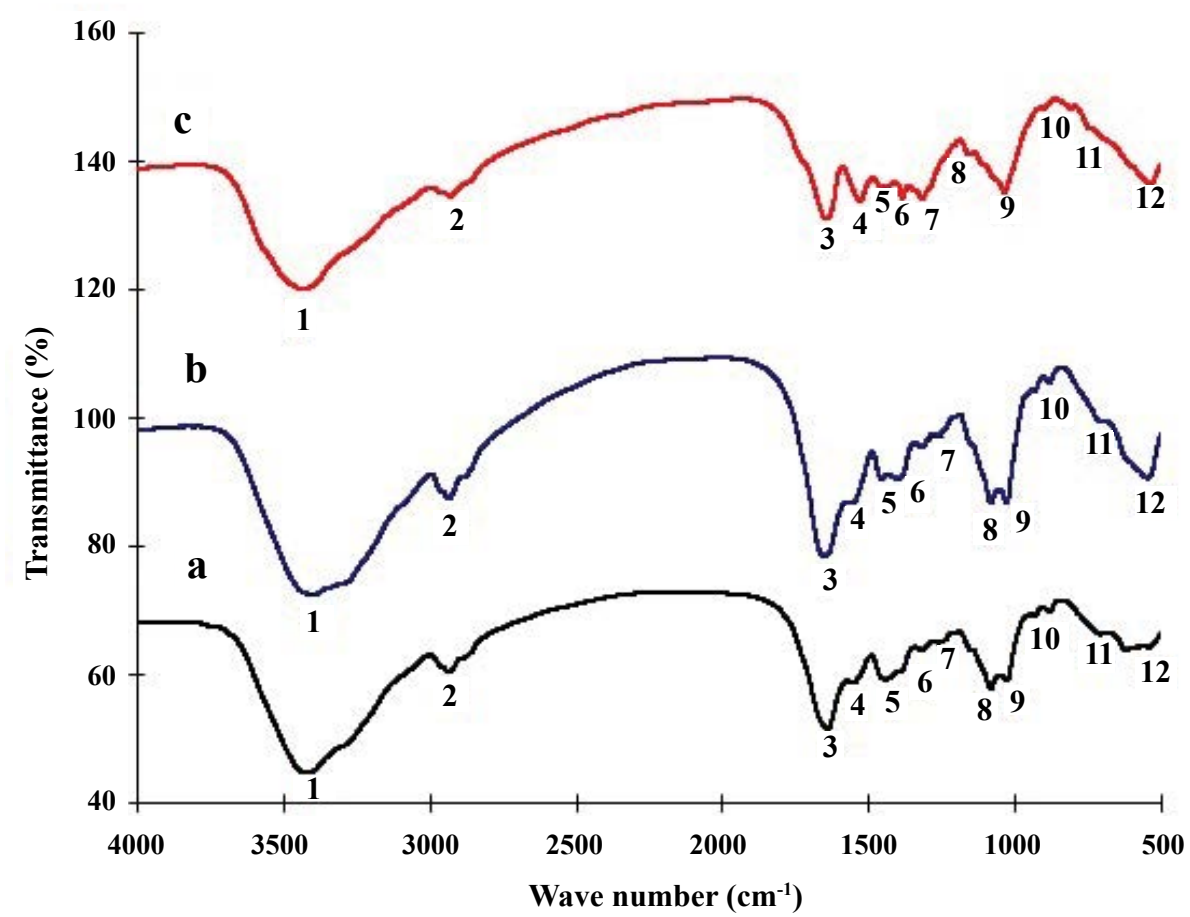

Figure 6: Infrared spectra of E. nigrum biomasses non-loaded (control) (a), modified with ferric chloride nanoparticles (b) and loaded (c) with $\mathrm{Th}(\mathrm{IV})$ ions. 
Citation: Hussien SS, Desouky OA, Elkattan M (2018) A New Approach for Utilization of Modified Epicoccum Nigrum Biomass by Ferric Chloride Nanoparticles for Biosorption of Thorium. Aspects Nanotechnol 1(1):40-51

stretching and bending vibrations of the functional groups that are involved in the biosorption of metal ions.

According to FT-IR spectra, it is suggested that there is a physical and chemical attraction between Th(IV) ions and the binding sites on the $E$. nigrum biomass. This interaction between Th(IV) ions and the sites on E. nigrum biomass modified the values of transmittance versus the wave number. Functional groups on E. nigrum have specific value of absorbance at different wave number (summarized in Table 1). Bonds at different wave numbers $(3422,2933,1639$,

Table 1: Elemental analysis of the dead biomass of E. nigrum.

\begin{tabular}{|l|l|l|l|l|}
\hline & $\begin{array}{l}\text { Dead biomass of } \boldsymbol{E} . \\
\text { nigrum }\end{array}$ & $\begin{array}{l}\text { After modification with ferric } \\
\text { chloride nanoparticles }\end{array}$ & $\begin{array}{l}\text { After biosorption of } \\
\text { thorium }\end{array}$ & After elution by $\mathbf{0 . 1}$ N HCl \\
\hline P & 1.85 & 7.44 & UDL & UDL \\
\hline S & 2.70 & 2.39 & UDL & UDL \\
\hline O & 14.33 & 3.44 & 2.09 & 2.37 \\
\hline N & 21.23 & 2.31 & 1.13 & 80.87 \\
\hline C & 55.88 & 14.87 & 2.02 & 1.13 \\
\hline K & 4.01 & 2.39 & 4.33 & 12.39 \\
\hline Fe & UDL & 67.16 & 90.43 & 100 \\
\hline Th & UDL & UDL & 3.25 \\
\hline Wt\% & 100 & 99.97 & 100.1 \\
\hline
\end{tabular}

UDL: Under detection limit.
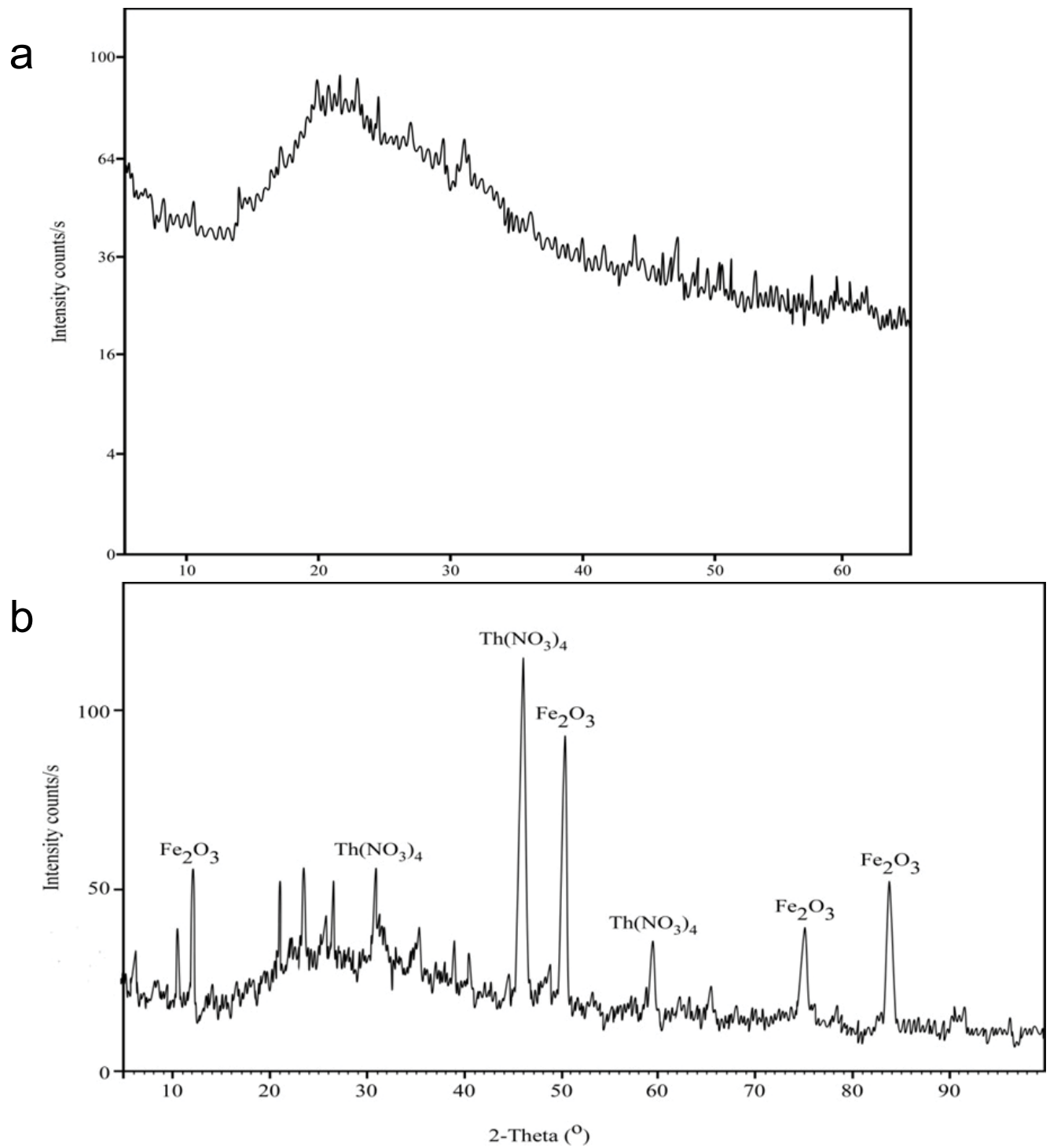

Figure 7: X-ray diffraction spectrum of (a) Control, modified biomass with ferric oxide nanoparticles; (b) Biomass after biosorption of thorium nitrate. 
Citation: Hussien SS, Desouky OA, Elkattan M (2018) A New Approach for Utilization of Modified Epicoccum Nigrum Biomass by Ferric Chloride Nanoparticles for Biosorption of Thorium. Aspects Nanotechnol 1(1):40-51

$1549,1439,1319,1260,1081,930,880,707$ and $540 \mathrm{~cm}^{-1}$ ) on E. nigrum before biosorption were detected as $\mathrm{O}-\mathrm{H}, \mathrm{C}-\mathrm{H}, \mathrm{C}=\mathrm{C}$, $\mathrm{N}-\mathrm{O}, \mathrm{O}-\mathrm{H}, \mathrm{C}-\mathrm{N}, \mathrm{C}-\mathrm{O}, \mathrm{C}-\mathrm{O},=\mathrm{C}-\mathrm{H}, \mathrm{C}-\mathrm{H}$ and $\mathrm{C}-\mathrm{X}$, respectively.

Values of transmittance and wave number of bonds on the $E$. nigrum after modified with ferric chloride nanoparticle has been changed due to forming new bonds. The new bonds formed at different wave number of 1650,1554 and $1452 \mathrm{~cm}^{-1}$ correspond to the bending vibrations of the $\mathrm{C}-\mathrm{N}$ of amide I, II and $\mathrm{C}=\mathrm{C}$ of aromatic group, respectively (Figure 6 and Table 2). The amide linkages between amino acid and residues of proteins in cell wall of fungal stain give rise to well-known signatures in the infrared region of the electro-magnetic spectrum. Such mode arises from peptides/proteins bound to ferric nanoparticles which suggest the possibility of this agent acting as a carrier and capping agents [31].

In this study, after saturating the biomass samples with Th(IV) ions, several bands shifts were observed in the FT-IR spectra in relation to pretreated biomass, especially those assigned to amide groups. The bands at 3393 and $2933 \mathrm{~cm}^{-1}$ were shifted to 3427 and $2926 \mathrm{~cm}^{-1}$, respectively.

The bands at 1650 and $1554 \mathrm{~cm}^{-1}$ were shifted to 1644 and $1528 \mathrm{~cm}^{-1}$, respectively (Figure 6). It is suggested that biosorption process is due to the interaction between thorium ions and amide groups within the available binding sites on biomass. The bands observed at $1318 \mathrm{~cm}^{-1}$ can be assigned to the $\mathrm{C}-\mathrm{N}$ stretching vibrations of the aliphatic amines was shifted to $1310 \mathrm{~cm}^{-1}$ (Figure 6) [32]. Such observations indicate the presence and binding of proteins to Th(IV) ions which can lead to their possible stabilization. In dead biomass probably the protein from the cell is liberated during the homogeneity process and bound on the surface cell. It was observed also appearance of band at $1385 \mathrm{~cm}^{-1}$, and this can be assigned to the $\mathrm{N}-\mathrm{O}$ stretching vibrations of nitro group and disappearance of band at $931 \mathrm{~cm}^{-1}$ can be attributed to

Table 2: Functional groups of E. nigrum biomasses and the corresponding infrared absorption wave lengths.

\begin{tabular}{|c|c|c|c|c|c|}
\hline $\begin{array}{l}\text { Type of } \\
\text { Biomass }\end{array}$ & $\begin{array}{l}\text { Functional } \\
\text { group }\end{array}$ & Type of compound and vibration & $\begin{array}{l}\text { Frequency } \\
\left(\mathrm{cm}^{-1}\right)\end{array}$ & $\begin{array}{l}\text { Reference frequency } \\
\text { range }\left(\mathrm{cm}^{-1}\right)\end{array}$ & Intensity \\
\hline \multirow{12}{*}{$\begin{array}{l}\text { Before } \\
\text { Biosorption }\end{array}$} & $\mathrm{O}-\mathrm{H}$ & Hydrogen bonded alcohols \& stretching & (1) 3422 & $3200-3600$ & Strong and broad \\
\hline & $\mathrm{C}-\mathrm{H}$ & Alkanes \& stretching & (2) 2933 & $2850-3000$ & Strong \\
\hline & $\mathrm{C}=\mathrm{C}$ & Alkenes \& stretching & (3) 1639 & $1648-1638$ & Variable \\
\hline & $\mathrm{N}-\mathrm{O}$ & Nitro \& stretching & (4) 1549 & $1550-1500$ & Strong \\
\hline & $-\mathrm{COO}-$ & Carboxylic acid \& bending & (5) 1439 & $1449-1395$ & Medium \\
\hline & $\mathrm{C}-\mathrm{N}$ & Amine \& stretching & (6) 1319 & $1080-1360$ & Medium \\
\hline & $\mathrm{C}-\mathrm{O}$ & Alkyl aryl ether \& stretching & (7) 1260 & $1000-1300$ & Strong \\
\hline & $\mathrm{C}-\mathrm{O}$ & Primary alcohol \& stretching & (8) 1081 & $1085-1050$ & Strong \\
\hline & $=\mathrm{C}-\mathrm{H}$ & Alkene \& bending & (9) 931 & $675-1000$ & Variable \\
\hline & $\mathrm{C}-\mathrm{H}$ & Aromatic (meta-substituted benzene) \& bending & (10) 880 & $860-900$ & Strong \\
\hline & $\mathrm{C}-\mathrm{H}$ & Aromatic (monosubstituted benzene) \& bending & (11) 707 & $700-750$ & Strong \\
\hline & $C-X$ & Chloroalkanes \& bending & (12) 540 & $540-760$ & Strong \\
\hline \multirow{12}{*}{$\begin{array}{l}\text { After modified } \\
\text { with } \mathrm{FeCl}_{3} \\
\text { nanoparticles }\end{array}$} & $\mathrm{O}-\mathrm{H}$ & Hydrogen bonded alcohols \& stretching & (1) 3393 & $3200-3600$ & Strong and broad \\
\hline & $\mathrm{C}-\mathrm{H}$ & Alkynes & (2) 2933 & $2850-3000$ & Strong \\
\hline & $\mathrm{N}-\mathrm{H}$ & Amine-amide I \& bending & (3) 1650 & $1650-1580$ & Medium \\
\hline & $\mathrm{N}-\mathrm{H}$ & Amine-amide II \& bending & (4) 1554 & $1540-1640$ & Medium \\
\hline & $\mathrm{C}=\mathrm{C}$ & Aromatic \& stretching & (5) 1452 & $1400-1600$ & Weak \\
\hline & C-N & Amine \& stretching & (6) 1319 & $1080-1360$ & Medium \\
\hline & $\mathrm{C}-\mathrm{O}$ & Alkyl aryl ether \& stretching & (7) 1261 & $1000-1300$ & Strong \\
\hline & $\mathrm{C}-\mathrm{O}$ & Primary alcohol \& stretching & (8) 1026 & $1085-1050$ & Strong \\
\hline & $=\mathrm{C}-\mathrm{H}$ & Alkene \& bending & (9) 930 & $675-1000$ & Variable \\
\hline & $\mathrm{C}-\mathrm{H}$ & Aromatic (meta-substituted benzene) \& bending & (10) 880 & $860-900$ & Strong \\
\hline & $\mathrm{C}-\mathrm{H}$ & Aromatic (monosubstituted benzene) \& bending & (11) 707 & $700-750$ & Strong \\
\hline & $C-X$ & Chloroalkanes \& bending & (13) 540 & $540-760$ & Strong \\
\hline \multirow{12}{*}{$\begin{array}{l}\text { Pretreated } \\
\text { biomass } \\
\text { after Th(IV) } \\
\text { biosorption }\end{array}$} & $\mathrm{O}-\mathrm{H}$ & Hydrogen bonded alcohols \& stretching & (1) 3427 & $3200-3600$ & Strong and broad \\
\hline & $\mathrm{C}-\mathrm{H}$ & Alkynes & (2) 2926 & $2850-3000$ & Strong \\
\hline & $\mathrm{N}-\mathrm{H}$ & Amine- amide I \& bending & (3) 1644 & $1650-1580$ & Medium \\
\hline & $\mathrm{N}-\mathrm{H}$ & Amine- amide II \& bending & (4) 1542 & $1540-1640$ & Medium \\
\hline & $\mathrm{C}=\mathrm{C}$ & Aromatic \& stretching & (5) 1453 & $1400-1600$ & Weak \\
\hline & $\mathrm{N}-\mathrm{O}$ & Nitro \& stretching & (6) 1381 & $1345-1385$ & Strong \\
\hline & $\mathrm{C}-\mathrm{N}$ & Amine \& stretching & (7) 1310 & $1080-1360$ & Medium \\
\hline & $\mathrm{C}-\mathrm{O}$ & Alkyl aryl ether \& stretching & (8) 1154 & $1000-1300$ & Strong \\
\hline & $\mathrm{C}-\mathrm{O}$ & Primary alcohol \& stretching & (9) 1032 & $1085-1050$ & Strong \\
\hline & $\mathrm{C}-\mathrm{H}$ & Aromatic (meta-substituted benzene) \& bending & (10) 860 & $860-900$ & Strong \\
\hline & $\mathrm{C}-\mathrm{H}$ & Aromatic (monosubstituted benzene) \& bending & (11) 740 & $700-750$ & Strong \\
\hline & $C-X$ & Chloroalkanes \& bending & (12) 540 & $540-760$ & Strong \\
\hline
\end{tabular}




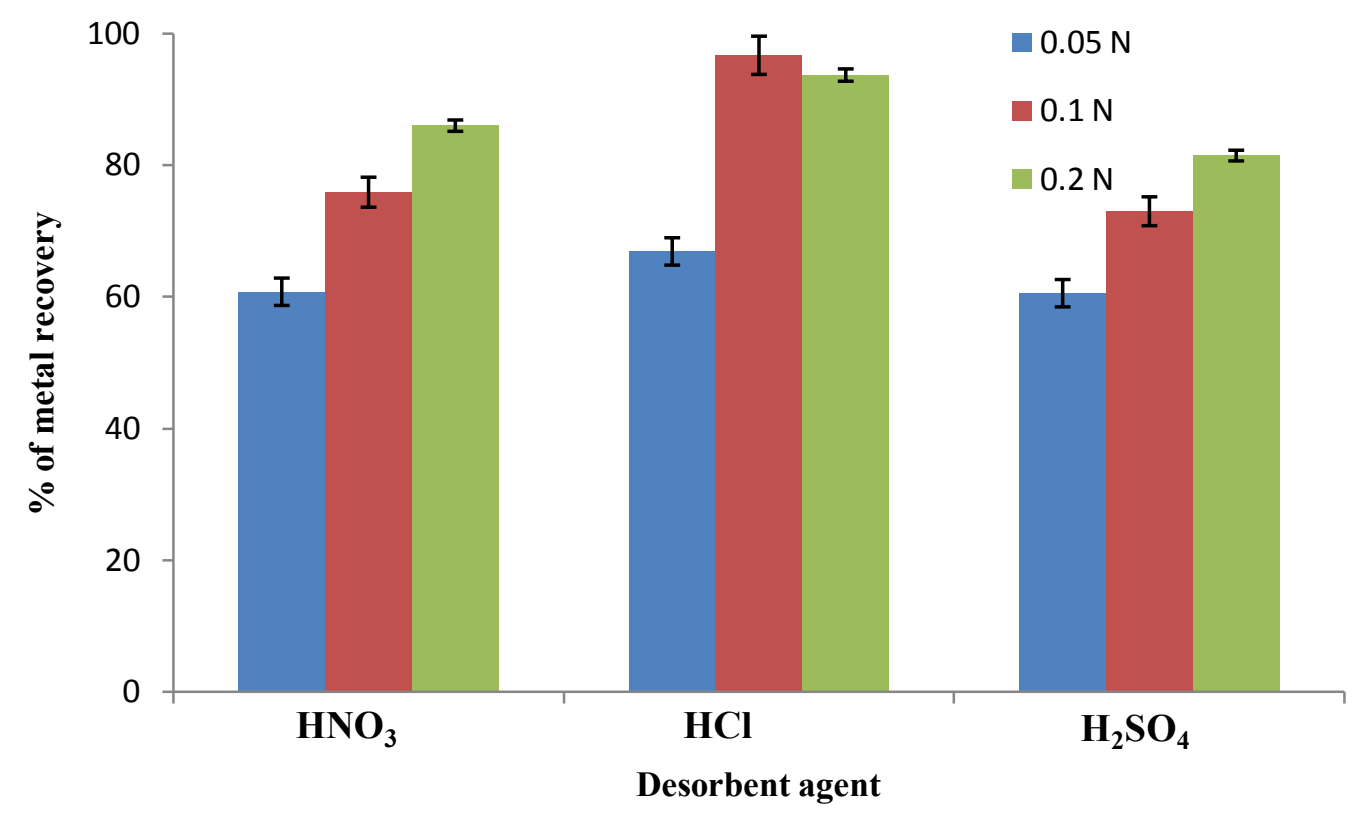

Figure 8: Desorption of Th(IV) ions with different desorbent agents.

the $=\mathrm{C}-\mathrm{H}$ bending vibration of alkenes.

The obvious explanation of a shift in the spectra, reduction and disappearance of the peaks are that there is an effect of chemical pretreatment and metal biosorption on the functional groups. These obtained results are in agreement with that obtained in [33].

X-ray diffraction (XRD): XRD analysis before and after Th(IV) biosorption are shown in Figure 7. In Figure 7a, there is a wide diffraction peak at the incident-beam $2 \theta$ of $14^{\circ}$ $30^{\circ}$, which is formed by polysaccharide and other organic ingredients. The shape of this peak indicated that the original absorbents had an amorphous structure. In Figure $7 b$, obtained X-ray diffraction spectrum shows distinct peaks indicating the deposition of crystallized hematite and thorium ions. Diffractogram of the hematite displayed maximum number of peaks to iron between $2 \theta$ of $50.36^{\circ}, 2 \theta$ of $77.35^{\circ}$ and $2 \theta$ of $84.49^{\circ}$ as illustrated in Figure $7 \mathrm{~b}$. Significantly $D$ values of most the peaks corresponding to iron chloride. Moreover, XRD pattern of Th(IV) loaded biomass Figure 7b is distinct and complex with some peaks narrowing and two new peaks emerging at $2 \theta$ of $32.04^{\circ}, 2 \theta$ of $47.30^{\circ}$ and $2 \theta$ of $60.35^{\circ}$, indicating deposition of thorium nitrate in the form of crystallized thorium. A similar result was obtained in [34].

\section{Desorption study}

In this section, desorption study was made to verify the possibility of desorbing the immobilized metal ions from the biomass. The percentage of desorbed Th(IV) ions from the biomass using hydrochloric, nitric and sulfuric acids at different concentrations for three washing cycles were shown in Figure 8. These desorbent agents were chosen because mineral acids appear to be the most feasibly applicable eluting agents. It was found that $0.1 \mathrm{~N} \mathrm{HCl}$ desorbent agent eluted about $94.89 \%$ of the biosorbed Th(IV) ions by $E$. nigrum biomass after three cycles. Higher acid concentrations could be resulted in higher concentration of protons that swept the metal ions away from the biosorbent. As expected, a slightly lower in weight loss could be achieved by $0.1 \mathrm{~N} \mathrm{HCl}$ compared to other acid concentrations. so, it safe to be used for desorption purpose without increasing the biomass weight loss [10]. In [35] it is mentioned that the most common acid concentration of $0.1 \mathrm{M} \mathrm{HCl}$ desorbed about $96 \%$ of Th(IV) ions from loaded biomass, deoiled karanja seed cake (DKSC) an agro-industrial waste resulted after expelling oil from the seeds.

\section{Thorium biosorption from (Th-U) concentrate solution}

Chemical composition of (Th-U) concentrate solution obtained from Egyptian monazite was presented as it consists of $20.07 \% \mathrm{RE}_{2} \mathrm{O}_{3}, 4.45 \% \mathrm{Fe}_{2} \mathrm{O}_{3}, 19.01 \% \mathrm{ThO}_{2}$ and $2.44 \% \mathrm{UO}_{2}$. In addition to, $\mathrm{CaO}, \mathrm{Na}_{2} \mathrm{O}, \mathrm{P}_{2} \mathrm{O}_{5}$ and loss of ignition (LOI) which presented in percentages $0.14 \%, 0.50 \%, 0.96 \%$ and $18.11 \%$, respectively [36]. Under the previously obtained optimum conditions for biosorption of Th(IV) ions, it was found that the percentage of removal Th(IV) ions from (Th-U) concentrate solution was to be $78 \%$. Furthermore, $87 \%$ of biosorbed Th(IV) ions were desorbed by $0.1 \mathrm{~N} \mathrm{HCl}$. Less removal of Th(IV) ions occurred in REEs solution as compared to synthetic Th(IV) ions solution might be attributed to the presence of interference of other rare earths in the solution that compete with Th(IV) ions for binding sites on the biosorbent. Similar observation was also reported in [37].

\section{Conclusion}

Dead biomass of the fungus $E$. nigrum was found to be an efficient tool for the uptake of thorium metal ions from aqueous solution. The dead biomass also acts as a stabilizer for the uptake of thorium ions during bioremediation processes. Th(IV) ions removal about $87.99 \%$ was observed after studying the optimum conditions. Results indicate that the presented novel approach for the bioremediation of 
Citation: Hussien SS, Desouky OA, Elkattan M (2018) A New Approach for Utilization of Modified Epicoccum Nigrum Biomass by Ferric Chloride Nanoparticles for Biosorption of Thorium. Aspects Nanotechnol 1(1):40-51

thorium ions is fast, low cost, environment friendly and easily scalable, using as reducing agent the fungus E. nigrum. SEM, XRD and IR spectra for $E$. nigrum biomass before and after adsorption of Th(IV) ions showed that different functional groups were involved in the biosorption of the metal ions. Furthermore, it was found that $E$. nigrum biosorbent uptake about $78 \%$ of Th(IV) ions from (Th-U) concentrate solution under the obtained optimum conditions. Removal of Th(IV) ions by $E$. nigrum biosorbent is in-line with alternative sustainable technology development for removal of Th(IV) ions from (Th-U) concentrate solution.

\section{References}

1. Diniz V, Volesky B (2005) Biosorption of La, Eu and Yb using Sargassum biomass. Water Res 39: 239-247.

2. Wu DB, Niu CJ, Li DQ, et al. (2004) Solvent extraction of scandium(III), yttrium(III), lanthanum(III) and gadolinium(III) using Cyanex 302 in heptane from hydrochloric acid solutions. Journal of Alloys and Compounds 374: 442-446.

3. Davis TA, Volesky B, Mucci A (2003) A review of the biochemistry of heavy metal biosorption by brown algae. Water Res 37: 43114330.

4. Varshney R, Bhadauria S, Gaur MS (2012) A review: Biological synthesis of silver and copper nanoparticles. Nano Biomed Eng 4: 99-106.

5. Mathialagan T, Viraraghavan T (2009) Biosorption of pentachlorophenol from aqueous solutions by a fungal biomass. Bioresour Technol 100: 549-558.

6. Zhou D, Zhang L, Zhou J, et al. (2004) Cellulose/chitin beads for adsorption of heavy metals in aqueous solution. Water Res 38 2643-2650.

7. Volesky B (2001) Detoxification of metal-bearing effluents: Biosorption for the next century. Hydrometallurgy 59: 203-216.

8. Salvadori MR, Ando RA, Nascimento CA, et al. (2015) Extra and intracellular synthesis of nickel oxide nanoparticles mediated by dead fungal biomass. PloS One 10.

9. Diniz V, Volesky B (2006) Desorption of lanthanum, europium and ytterbium from Sargassum. Separation and Purification Technology 50: 71-76.

10. Anand P, Isar J, Saram S, et al. (2006) Bioaccumulation of copper by Trichoderma viride. Bioresour Technol 97: 1018-1025.

11. Raju CSK, Subramanian MS, Sivaraman N, et al. (2007) Retention studies on uranium, thorium and lanthanides with amide modified reverse phase support and its applications. J Chromatogr A 1156: 340-347.

12. Gok C, Aytas S (2013) Recovery of thorium by high capacity biopolymeric sorbent. Separation Science and Technology 48: 2115-2124.

13. Gleiter H (1989) Nanocrystalline materials. Progress in Materials Science 33: 223-315.

14. Conte M, Prosini PP, Passerini S (2004) Overview of energy/ hydrogen storage: State-of-the-art of the technologies and prospects for nanomaterials. Materials Science and Engineering B 108: 2-8.

15. Oujezdsky KB, Grove SN, Szaniszlo PJ (1973) Morphological and structural changes during the yeast-to mold conversion of Phialophora dermatitidis. J Bacteriol 113: 468-477.
16. Salvadori MR, Lepre LF, Ando RA, et al. (2013) Biosynthesis and uptake of copper nanoparticles by dead biomass of Hypocrea Lixii isolated from the metal mine in the Brazilian Amazon region. PloS One 8: e80519.

17. Marczenko Z (1976) Spectrophotometric determination of elements. John Wiley \& Sons, New York.

18. Sert S, Kütahyali C, Inan S, et al. (2008) Biosorption of lanthanum and cerium from aqueous solutions by Platanus orientalis leaf powder. Hydrometallurgy 90: 13-18.

19. Purvis OW, Halls C (1996) A review of lichens in metal-enriched environments. The Lichenologist 28: 571-601.

20. Veglio F, Beolchini F (1997) Removal of metals by biosorption: A review. Hydrometallaurgy 44: 301-316.

21. Hussien SS (2014) Biosorption of lanthanum from aqueous solution using Pleurotus ostreatus basidiocarps. Int J Biotech Res 2: 026-036.

22. Kapoor A, Viraraghavan T, Cullimore DR (1999) Removal of heavy metals using the fungus Aspergillus niger. Bioresource Technology 70: 95-104.

23. Zhou JL (1999) Zn biosorption by Rhizopus arrhizus and other fungi. Applied Microbiology and Biotechnology 51: 686-693.

24. Hussien SS, Desouky OA (2014) Biosorption studies on yttrium using low cost pretreated biomass of Pleurotus ostreatus. $4^{\text {th }}$ Int Con Rad Res Appl Sci 139-150.

25. Ozer A, Ozer D (2003) Comparative study of the biosorption of $\mathrm{Pb}(\mathrm{II}), \mathrm{Ni}(\mathrm{II})$ and $\mathrm{Cr}(\mathrm{VI})$ ions onto S. cerevisiae: Determination of biosorption heats. J Hazard Mater 100: 219-229.

26. Vijayaraghavan K, Mahadevanb A, Joshi UM, et al. (2009) An examination of the uptake of lanthanum from aqueous solution by crab shell particles. Chem Eng J 152: 116-121.

27. Pagnanelli F, Petrangeli MP, Trifoni M, et al. (2000) Biosorption of metal ions on Arthrobacter sp.: Biomass characterization and biosorption modeling. Environ Sci Technol 34: 2773-2778.

28. Meena KA, Mishra GK, Rai PK, et al. (2005) Removal of heavy metal ions from aqueous solutions using carbon aerogel as an biosorbent. J Hazard Mater 122: 161-170.

29. Liu YG, Fan T, Zeng GM, et al. (2006) Removal of cadmium and zinc ions from aqueous solution by living Aspergillus niger. Transactions of Nonferrous Metals Society of China 16: 681-686.

30. Carol D, Kingsley SJ, Vincent S (2012) Hexavalent chromium biosorption from aqueous solutions by Pleurotus ostreatus spent biomass. Int J Eng Sci and Tech 4: 7-22.

31. Bansal V, Ahamad A, Sastry M (2006) Fungus-mediated biotransformation of amorphous silica in rice husk to nanocrystalline Silica. J Am Chem Soc 128: 14059-14066.

32. Vigneshwaran N, Kathe AA, Varadarajan PV, et al. (2007) Silver-protein (core-shell) nanoparticle production using spent mushroom substrate. Langmuir 23: 7113-7117.

33. Qing CHEN (2010) Study on the biosorption of lanthanum(III) from aqueous solution by bamboo charcoal. Journal of Rare Earths 28: 125-131.

34. Desouky OA, El-Mougith AA, Hassanien WA, et al. (2016) Extraction of some strategic elements from thorium-uranium concentrate using bioproducts of Aspergillus ficuum and Pseudomonas aeruginosa. Arabian Journal of Chemistry 9: S795-S805. 
Citation: Hussien SS, Desouky OA, Elkattan M (2018) A New Approach for Utilization of Modified Epicoccum Nigrum Biomass by Ferric Chloride Nanoparticles for Biosorption of Thorium. Aspects Nanotechnol 1(1):40-51

35. Varala S, Suresh KB, Parthasarathy R, et al. (2017) Desorption studies for the recovery of thorium from loaded biosorbent (DKSC): Parameter optimization and equilibrium modelling. International Journal of Advances in Science Engineering and Technology 5: 55-58.

36. Desouky OA (1998) Solvent extraction mechanism study on
uranium(VI) and thorium(IV) from sulfuric acid solution and its technological application [thesis]. Zagazig University, Egypt.

37. Katsumata H, Kaneco S, Inomata K, et al. (2003) Removal of heavy metals in rinsing wastewater from plating factory by adsorption with economical viable materials. J Environ Manage 69: 187-191. 